\title{
As Concepções Etnocêntricas do Genocídio de Ruanda: a Negação do Sujeito Histórico Ruandês
}

\author{
Danilo Ferreira da Fonseca ${ }^{1}$
}

\section{Resumo}

O presente artigo busca entender como são desenvolvidas as diferentes análises acerca do genocídio ruandês de 1994 e também seu caráter etnocêntrico, o que acaba por marginalizar o sujeito histórico africano de sua própria história. A partir das principais estruturas explicativas do genocídio, busca-se entender, ponto-a-ponto, como o entendimento acerca do genocídio de Ruanda possui uma ampla influência de uma visão etnocêntrica.
\end{abstract}

Palavras Chaves: Ruanda; Genocídio; Etnocentrismo.

\begin{abstract}
This article search to understand how the different reviews about the Rwandan genocide of 1994 are developed and also its ethnocentric character, which ultimately marginalize the African historical subject of their own history. From the major explanatory for the genocide, we search to understand, point-to-point, how the understanding of the genocide in Rwanda has a large influence of an ethnocentric view.
\end{abstract}

Key-words: Rwanda; genocide; Ethnocentrism.

\section{Introdução}

Em Ruanda - um minúsculo país da África Central, daqueles que no mapa mundial possuem um número ao invés do nome - no dia seis de abril de 1994, logo após a queda do avião presidencial de Juvenal Habyarimana, milhares de ruandeses da capital Kigali que se entendiam e se denominavam como hutus pegaram suas armas, formaram barricadas, e invadiram casas e outros locais em que estavam seus vizinhos que se entendiam e se denominavam tutsis, matando-os com uma organização particular.

Em poucos dias, praticamente todas as regiões de Ruanda estavam tomadas por este movimento. Armados principalmente com facões e com um discurso de eliminação dos inyenz̧i (baratas), termo utilizado para designar os que eram considerados tutsis naquele momento.

Em pleno fim do século XX, por pouco mais de cem dias, o mundo assistiu incrédulo, estarrecido e aparentemente impotente, pessoas que, durante séculos, haviam interagido em todos os âmbitos da sociabilidade, por meio de casamentos, negócios,

\footnotetext{
${ }^{1}$ Professor universitário, Mestre e doutorando em História Social pela PUC-SP, com a pesquisa "Etnicidade e conflitos sociais na África contemporânea: o genocídio ruandês (1959 - 1994) e o Apartheid Sul-africano (1948 - 1994)". Contato: daniloffonseca@gmail.com
} 
produções, relações parenterais, amizades, disputas quotidianas, organizações civis, festas, ritos e comemorações, transformarem seus instrumentos de trabalho - o facão, em uma arma usada para matar quem fosse considerado o inimigo mais próximo.

Por meio dos meios de comunicação, dos agentes internacionais, dos analistas políticos para lá enviados, das denúncias e pedidos de socorro, soube-se, simplificadamente, que os hutus de Ruanda estavam matando seus vizinhos tutsis o que culminou com a morte, calculada entre 500 mil a 1 milhão de ruandeses promovendo o último genocídio do século XX.

Tal movimento histórico suscitou uma série de dúvidas e questionamentos ao mundo ocidental, diversos intelectuais se perguntavam o que teria causado tal ferocidade, ou quais fatores haviam levado estes serem humanos, que haviam constituído uma organização societária por séculos, a tal desumanização. A tais questões foram inicialmente dadas respostas rápidas, muitas delas, conforme veremos, a partir da exterioridade daquela cultura, da forma de ser social dos indivíduos envolvidos naquele massacre.

Entender o desenvolvimento destas repostas apressadas que foram elaboradas por uma série de analistas acerca do genocídio ruandês e seu processo histórico, é o propósito do presente artigo.

Num século permeado por genocídios, iniciado pelo genocídio Armênio em 1917 e passando pelo Holocausto na década de 1940, a finalização ficou por conta do genocídio de Ruanda de 1994. Muitas vezes o que impera nas discussões acerca destes processos históricos são detalhes mais imediatistas, como os modos de se perpetuar os determinados acontecimentos ou a quantidade de vidas tomadas no período.

Estas preocupações imediatistas acabam por esvaziar o entendimento do próprio processo histórico, deixando todo um complexo movimento histórico e cultural, fundamentais para o seu entendimento, marginalizados na análise, e sem perceber que um momento de crise que envolva um genocídio muitas vezes mina como um rio subterrâneo, ou seja, a concretização de uma ação genocida se apresenta como resultante de um longo processo, após ter percorrido um longo caminho submerso e nem sempre percebido empiricamente, ou deixando muito claro os caminhos construídos que culminaram naquele ponto, embora se manifeste apenas em sua contemporaneidade, como algo imediatamente posto. 
A literatura dominante acerca de Ruanda vai analisar o caminho obscuro percorrido subterraneamente pelas águas, de acordo com o local e modo que ela mina, supondo sua trajetória com métodos elaborados e sofisticados, mas esquecendo que o rio da história percorre múltiplos caminhos e desvios que muitas vezes não condiz com o que, à primeira vista, lhe salta aos olhos.

Referimo-nos às abordagens que resumem esse genocídio a um conflito entre duas etnias e que se restringem à reprodução de evidências empiricamente colocadas no momento imediato do genocídio. Em 1994 caso um hutu fosse questionado sobre os motivos de sua ação, ele próprio colocaria que as executava porque os tutsis pertenciam a uma outra etnia, diferente da sua - hutu, denotando que o problema se resumia a uma polarização entre duas etnias rivais. Nesta perspectiva a história de Ruanda se resume a uma acumulação progressiva de ódio e violência que chega ao seu ápice com o genocídio em 1994. Como se existisse uma teleologia da história ruandesa que culminaria com o genocídio.

Ainda dentro desta perspectiva reducionista bipolarizada entre tutsis e hutus, despontam diferentes explicações para múltiplos porquês acerca do genocídio ruandês, formando um recente debate historiográfico. Porém, quando se enfatiza o caráter étnico do conflito dentro de Ruanda, se dá margem a que "as principais narrativas correntes sobre o genocídio ruandês sejam despolitizantes, essencialistas e a-históricas".

Para esclarecermos melhor este debate historiográfico acerca da história ruandesa, utilizamos como ponto de partida um importante levantamento sobre as diferentes concepções e explicações do genocídio de Ruanda, feito por Ana Cristina Alves em sua dissertação de mestrado (2005), que pode nos auxiliar a entender este recente debate. Esta autora, ao analisar diferentes obras acerca do genocídio em questão, vai identificar três diferentes explicações possíveis para o acontecimento, cujas análises em muito se comunicam e se complementam, podendo até coexistir numa mesma perspectiva, com autores percorrendo por mais de uma tendência. Podemos colocar como tendências explicativas do genocídio, três diferentes explicações:

(1) a influência externa, principalmente nas formas:

\footnotetext{
2 ALVES, Ana Cristina. Contos sobre Ruanda: Uma análise crítica sobre o genocídio ruandês de 1994. Dissertação (mestrado). Pontifícia Universidade Católica do Rio de Janeiro, Instituto de Relações Internacionais, 2005, p. 71.
} 
(a) o legado da colonização e

(b) o legado das intervenções das grandes potências no Estado ruandês durante as décadas de 1980 e 1990;

(2) a luta pela sobrevivência suscitada pela escassez de recursos ecológicos;

(3) a manipulação das elites sobre as massas obedientes. ${ }^{3}$

Assim observa-se que, embora ainda centrados no paradigma da etnicidade, tais abordagens explicitam questionamentos distintos acerca do processo histórico ruandês.

\section{Entendendo o genocídio a partir da influência externa}

A estrutura explicativa destacada anteriormente, intitulada "a influência externa", considera a ação de agentes estrangeiros à população ruandesa como o fator desencadeador do genocídio. Esta concepção, ao colocar a centralidade do movimento histórico ruandês em agentes externos, acaba por expandir uma visão que entende a África como um local submisso e atrasado. Vê o povo africano com um povo infantilizado, dada a vigência de formas culturais entendidas como "primitivas" e que, ante as artimanhas do "civilizado", é facilmente ludibriado, levando-o a cometer atos irresponsáveis, cabendo assim a um adulto responsável tutelá-lo até a civilização.

Para tais autores, a má influência adviria do poder colonial Belga que teria, durante todo período colonial, fomentado o ódio entre as duas etnias. Alguns apontam que, diante de um passado pré-colonial mais harmonioso, tal ódio teria sido propositadamente gestado.

Observa-se que os autores analisados por Alves partem do preceito segundo o qual séries de tribos e ou etnias rivais são consideradas integrantes de um mesmo Estado moderno, conforme determinado pela Conferência de Berlim de 1885. Nesta Conferência a África foi dividida entre as potências européias iniciando-se, assim, um novo processo colonialista. Tal processo teria levado os grupos rivais que ficaram no mesmo território a se articularem de diferentes modos, resultando daí dezenas de guerras civis e milhões de mortos, as quais teriam se acentuado com o fim do colonialismo. Neste sentido, as guerras e conflitos africanos do século XX são colocados muitas vezes, tanto pela mídia como por alguns acadêmicos como decorrência do final do processo colonial, como se a saída dos europeus do continente

\footnotetext{
${ }^{3}$ ALVES, Ana Cristina. Op. cit. p. 64.
} 
africano tirasse seu lado civilizado e civilizatório (o europeu), ficando assim apenas o selvagem (o africano).

Neste sentido, o genocídio ruandês em sua contemporaneidade teria sido o resultado da ausência de interação étnica e da incapacidade dos ruandeses de implementar um Estado Moderno fundado em preceitos civilizatórios, cuja complexidade seria inatingível para estes grupos - daí que a catástrofe seria inevitável. Podemos observar esta concepção em Silva (2003), para o qual "os anos de constante acirramento do ódio étnico entre as duas etnias majoritárias de Ruanda levaram à abertura dessa violenta Caixa de Pandora nos momentos imediatamente posteriores à independência". Nesta visão podemos observar que a violência entre os dois grupos "étnicos" ruandeses ocorre "imediatamente" após a saída do europeu de Ruanda, como se este segurasse a civilidade na região.

Tais pré-conceitos atribuídos aos conflitos étnicos africanos são substratos fundantes nas análises sobre o genocídio ruandês em que pesam os diferentes entendimentos sobre os motivos que levaram a este acontecimento.

Em nosso entender, mesmo em sua crítica aos colonizadores, essas concepções acabam desconsiderando a importância das tradições locais e super valorizando as influências da dominação, no caso, dos belgas, como se estas pudessem apagar o passado ruandês, sua cultura, suas tradições e reescrever tal passado do modo que bem entendessem, como podemos observar no seguinte trecho de Gourevitch (2006):

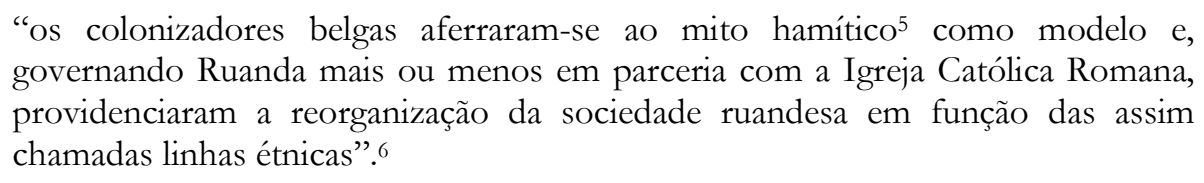
governando Ruanda mais ou menos em parceria com a Igreja Católica Romana, providenciaram a reorganização da sociedade ruandesa em função das assim chamadas linhas étnicas". ${ }^{6}$

Também tem sido enfatizado pelos autores que se colocam de forma crítica aos agentes internacionais que teriam influenciado no genocídio, o apoio da França à ditadura de

\footnotetext{
${ }^{4}$ SILVA, Alexandre S. A intervenção humanitária em três quase-Estados africanos: Somália, Ruanda e Libéria. Dissertação (mestrado). Pontifícia Universidade Católica do Rio de Janeiro, Instituto de Relações Internacionais, 2003, p. 69.

5 O mito hamítico é um mito bíblico que conta a trajetória dos irmãos Caim e Abel. Um mito muito utilizado dentro do processo histórico ruandês, e na historiografia, para explicar a relação aposta entre as etnias tutsis e hutus.

${ }^{6}$ GOUREVITCH, Philip. Gostariamos de informá-lo de que amanhã seremos mortos com nossas famílias. São Paulo, Companhia das letras, 2006, p 54
} 
Habyarimana ${ }^{7}$ entre os anos de 1973 a 1994, vendendo-lhe armas e treinamento militar para impulsionar os combates entre o governo e a oposição no início da década de 1990, como é o caso de Kapuscinski, ${ }^{8}$ que afirma em sua obra Ébano (2002) que:

\begin{abstract}
"não fosse um telefonema, provavelmente também se teria evitado a hecatombe, os massacres e a carnificina de 1994 - o telefonema do general Habyarimana ao presidente Mitterrand, pedindo ajuda' (...).'As colunas da Frente Patriótica Ruandesa9 já estavam próximas a capital e o clã e o governo Habyarimana já tinham as malas prontas, quando paraquedistas franceses chegaram ao aeroporto de Kigali. Eram apenas duas companhias, mas bastaram"'. ${ }^{10}$
\end{abstract}

No entanto, por restringirem suas análises à "influência externa" e às "intervenções das grandes potências no Estado ruandês durante as décadas de 1980 e 1990", a especificidade vigente na região fica subsumida, na mesma proporção dos autores que analisam a questão Belga naquele país.

Respalda a análise desses autores, o fato do governo ruandês pós-genocídio, formado pela oposição ao governo Habyarimana, acusar frequentemente a França de ter participado ativamente do genocídio. A chamada “operação turquesa” realizada em julho de 1994 pela França estabeleceu uma zona de segurança que perpetuou o genocídio em seu interior - daí as acusações. Este também é um ponto trabalhado por outro autor, no caso, Gourevitch (2006) que após entrevistar um dos principais líderes na luta contra o genocídio e o governo ruandês, Paul Kagame, ${ }^{11}$ também responsabiliza a França pelo desencadear daquele conflito:

A Operation Turquoise acabou ganhando crédito pelo resgate de pelo menos 10 mil
tutsis no oeste de Ruanda, mas outros milhares continuavam a ser mortos na zona
ocupada pelos franceses. Brigadas do Poder Hutu ${ }^{12}$ adornavam seus carros com
bandeiras francesas para atrair tutsis para fora de seus esconderijos e os levar para a
morte; e mesmo quando tropas francesas verdadeiras encontravam sobreviventes, elas
freqüentemente lhes dizia para esperar por transporte, iam embora e quando voltavam
descobriam que aqueles que haviam salvado eram agora cadáveres. Desde o momento
em que chegaram os franceses, e aonde quer que fossem, as forças francesas

\footnotetext{
7 O General Juvenal Habyarimana foi o presidente da Segunda República Ruandesa (1973 - 1994), governando o país por mais de 20 anos, Habyarimana participou do golpe de estado de 1973, que pôs fim a Primeira República Ruandesa (1962 - 1973) e o colocou como presidente, porém com amplas características ditatoriais.

${ }^{8}$ KAPUSCINSKI, Ryszard. Ébano: Minha vida na África. São Paulo, Companhia das Letras, 2002.

9 A Frente Patriótica Ruandesa (FPR) foi uma oposição armada ao governo Habyarimana criada na década de 1980, formada por exilados e oposicionistas do governo ruandês.

${ }^{10}$ Idem, pp. 197; 199.

11 Paul Kagame foi líder oposicionista ao governo Habyarimana, um dos fundadores da FPR, e membro do governo pós genocídio - chegando a presidir o país.

${ }^{12}$ O poder hutu foi um importante movimento do início da década de 1990,
} 
sustentaram e preservaram os mesmos líderes políticos locais que comandaram o genocídio. $^{13}$

Ambas as perspectivas, apontam que a Organização das Nações Unidas (ONU) deveria ter assumido a tutela de Ruanda para evitar que esta ficasse submetida a más influências, embora procedam as duras críticas ao papel da United Nations Assistance Mission for Rwanda (UNAMIR) naquele país. Philip Gourevitch (2006) é um dos autores que desenvolve extensas páginas acerca da incapacidade internacional de atuar no sentido de evitar o genocídio, como podemos ver no seguinte trecho retirado de sua obra:

Ruanda é um país paupérrimo (...) no que diz respeito aos interesses políticos, militares e econômicos das potências mundiais, tem tanta importância quanto Marte. Mas Ruanda, ao contrário de Marte, é povoada por seres humanos, e quando Ruanda sofreu o genocídio, as potências mundiais abandonaram-na à própria sorte. ${ }^{14}$

Em tais estudos o genocídio em si e a ação do próprio povo ruandês ficam subsumidos, como que mergulhados na inocência de um país tribal, ou primitivo, que ainda não conhece a civilização. Assim, em muitas obras a principal preocupação não é entender e elucidar o genocídio em si, mas sim apontar os culpados, denunciando-se tanto a invasão colonial quanto a falta de uma tutela mais consistente como fatores determinantes do processo genocida. Neste sentido, ficam subsumidos o conjunto dos fatores internos que se gestam para além de tal conjuntura, embora integrados a ela.

Esta concepção acerca do genocídio, de uma "influência externa", possui uma ampla comunicação com a terceira apontada anteriormente por Alves (2005), ou seja, a explicação de que o genocídio foi decorrente de uma "manipulação das elites sobre as massas obedientes".

\section{O genocídio como produto da passividade do ruandês}

A análise que possui a estrutura explicativa denominada como a "manipulaşão das elites sobre as massas obedientes", é uma das mais presentes na literatura acerca do genocídio ruandês, sendo amplamente desenvolvida por autores como o já citado Philip Gourevitch (2006), Scott

\footnotetext{
13 GOUREVITCH, Philip. Gostariamos de informá-lo de que amanhã seremos mortos com nossas famílias. São Paulo, Companhia das letras, 2006, p. 154.

${ }^{14}$ Idem, p 146.
} 
Straus (2006), ${ }^{15}$ Berkeley (2001), ${ }^{16}$ entre outros. Para estes autores que constroem tal argumentação baseada na "manipulação", o genocídio seria resultante de uma manobra política da elite local - identificada como o clã $A k a z u^{17}$ - para realizar uma manutenção de seu poder. Nessa perspectiva uma série de matérias via imprensa, educação, entre outros meios, teria sido desencadeada visando acentuar a rivalidade entre as etnias hutu e a tutsi, manipulando assim a opinião pública ruandesa, instigando-os ao genocídio. Berkeley (2001) é um dos pesquisadores que divulga esta concepção:

\begin{abstract}
"Estava claro que os massacres haviam sido orquestrados pelo Estado. (...) mas como isso foi possível? O genocídio de Ruanda matou mais pessoas mais rapidamente do que qualquer outra chacina na história documentada. A velocidade sem precedentes da matança não teria sido possível sem a participação de centenas de milhares de cidadãos comuns (...) [Akazu] personificava a sociedade rigidamente hierárquica e uma cultura de obediência, sem as quais a matança em tal escala não seria possível". ${ }^{18}$
\end{abstract}

Pode-se observar a ênfase na ideia da existência de uma característica ruandesa centrada em uma "cultura da obediência". Ou seja, a subserviência, aliada à ambição da elite dirigente, teriam gestado o genocídio. Assim, diferentemente dos autores anteriores, aqui se considera um fator interno, no caso, atribuído a uma possível característica ruandesa ainda de fundo desqualificador, ou seja, a fácil sujeição à manipulação.

Também se recorre a esta "cultura da obediência" para explicar outros momentos do processo histórico ruandês, como, por exemplo, o avanço do cristianismo no país. Conforme é desenvolvido por Desforges, a população ruandesa simplesmente obedeceu aos seus chefes locais, deixando de lado suas tradicionais práticas sociais e religiosas, já que, "não poderiam permanecer parados, enquanto seus superiores estavam ajoelhados rezando". ${ }^{19}$

Assim como a lógica explicativa da "influência externa", esta da "manipulaşão das elites" subsume o povo ruandês enquanto um agente social histórico ativo, tomando-o enquanto seres passivos, facilmente manipuláveis e suscetíveis a influências externas, sem demonstrar resistências.

${ }^{15}$ STRAUS, Scott. The order of the genocide: race, power, and war in Rwanda, Ithaca, Cornell University Press, 2006.

${ }^{16}$ BERKELEY, Bill. The graves are not yet full: Race, tribe and power in the heart of Africa. New York, Basic book, 2001.

17 Composta por um grupo de pessoas próximas ao presidente Habyarimana da segunda República Ruandesa $(1973-1994)$.

${ }_{18}$ BERKELEY, Bill. The graves are not yet full: Race, tribe and power in the heart of Africa. New York, Basic book, 2001, pp. $253-254$.

19 Prosector v. Ferdinand Nabimana, Jean-Bosco Barayagwiza and Hassan Ngeze: Case No. ICTR-99-52-T/Judgement and setence, dezembro de 2003, p 30. 
Nota-se também nesta explicação uma excessiva centralidade na figura do Estado. Este destaque ao poder instituído se dá devido a sua proximidade com uma lógica do analista, ou seja, o Estado seria aquilo dentro da particularidade ruandesa, que mais se aproximaria de uma lógica social ocidental, desconsiderando conjuntamente uma possibilidade de haver em Ruanda uma estrutura de poder e simbologia distinta daquela encontrada no ocidente.

Esta frequente alusão ao Estado, nesta estrutura explicativa exposta, pode ser apontada como mais um desenvolvimento etnocentrista, já que ocorre uma série de "transferências de valores interculturais dos conceitos ocidentais" 20 . No caso, são valorizadas as características ocidentais da figura de um Estado, enquanto que nos momentos em que ocorrem desencontros desta figura com a realidade específica ruandesa, o que é observado normalmente são termos desqualificadores.

\section{A escassez dos recursos ecológicos}

Finalmente, as análises que entendem o genocídio ruandês a partir da "escassę dos recursos ecológicos", possuem um embasamento teórico e algumas pré-concepções distintas sobre as relações sociais no continente africano, não participando diretamente da visão que atribui à Conferência de Berlim, ou outros agentes externos como a ação dos belgas ou franceses, ou ainda à submissão e subserviência de agentes internos, o fator preponderante dos confrontos sociais africanos contemporâneas.

Tais autores consideram "o princípio da escassez", baseado na lei de Say, o fator preponderante do genocídio. Tais autores, ao tomarem a perspectiva de Malthus sobre o crescimento geométrico da população em contraposição à produção de alimentos (que cresceria em ritmo aritmético), e ao associarem ao preceito advindo da microeconomia de que não é possível produzir em qualquer sociedade tudo para todos, acabam por criar um novo paradigma. Ou seja, a escassez de alimentos teria gestado o genocídio. Tal analítica salienta o fenômeno observado em Ruanda no momento do genocídio, pois era o país mais populoso da África, com índices de crescimento populacionais altíssimos e com uma economia agrária precária, como aponta Scott Straus (2006):

\footnotetext{
${ }^{20}$ LE GOFF, Jacques. História e Memória. Campinas, Editora da Unicamp, 1990, p 138.
} 


\begin{abstract}
"Ruanda é o país mais densamente povoado da África e um dos mais densamente povoados do mundo. Ruanda também é uma terra ondulada, de colinas cultivadas. Há muito pouco espaço aberto ainda não cultivado no país. Como resultado, a população do país é muito mais vulnerável, particularmente em áreas rurais, e há muito pouco espaço físico para escapar".21
\end{abstract}

Somado a "catástrofes climáticas e (a)o man gerenciamento dos recursos [que] criaram bolsões de fome", ${ }^{22}$ conforme aponta Gourevitch, era de se esperar que em determinado momento a população precisasse ser reduzida de alguma forma, levando os ruandeses, ao sentirem a escassez de seus recursos, a se unirem de acordo com a etnia a que pertencessem e, a partir do genocídio, estabilizassem a oferta de alimentos.

A crise alimentar que Ruanda sofreu no início da década de 1990 não foi a primeira e nem a única, e nesses momentos a situação não foi solucionada com o uso da violência. A explicação da "escassez dos recursos" acaba assim, por desconsiderar a história ruandesa, sem inquirir diretamente como eram os modos de produção social em Ruanda, como estes recursos eram distribuídos, e sem situar o movimento histórico que precede o genocídio.

Ou seja, de uma forma ou de outra, Ruanda (e, pode-se aventar, o continente africano como um todo), é colocada como atrasada e selvagem, destituída de civilização, em que, segundo Silva (2003), "uma psicopatia tomou conta da população Hutu, muito bem dirigida pelos extremistas, levando-a a barbárie hobbesiana e ao genocídio(...)”.". Sendo assim, para esta perspectiva analítica, o genocídio ruandês é atribuído à barbárie no qual o continente africano ainda estaria imerso, sem um Estado consolidado para regular as questões individuais na esfera pública.

\title{
A origem e formação de tutsis e hutus
}

A tese da determinação do processo colonizador também adentra às reflexões que buscam entender as questões étnico-raciais e suas circunstâncias históricas. Quando o debate

${ }^{21}$ STRAUS, Scott. The order of the genocide: race, power, and war in Rwanda, Ithaca, Cornell University Press, 2006, p. 8.

22 GOUREVITCH, Philip. Gostariamos de informá-lo de que amanhã seremos mortos com nossas famílias. São Paulo, Companhia das letras, 2006, p. 97.

${ }^{23}$ SILVA, Alexandre S. A intervenção humanitária em três quase-Estados africanos: Somália, Ruanda e Libéria. Dissertação (mestrado). Pontifícia Universidade Católica do Rio de Janeiro, Instituto de Relações Internacionais, 2003, p.70. 
acerca do genocídio ruandês adentra à recuperação dos aspectos históricos em busca de explicá-lo, emergem questionamentos sobre as identidades dos tutsis e dos hutus e sobre o seu significado neste processo histórico. Tal aspecto pode ser consolidado em duas distintas concepções sobre a origem e a dinâmica destes grupos: (1) a visão de que são grupos étnicos pré-existentes à colonização, e (2) a concepção de que estes são grupos criados e gestados pelo poder colonial.

Para a primeira visão, partilhada por escritores como Mamdani (2002) e Kapuscinski $(2002)^{24}$ e assumido por Silva (2003), já citado, tutsis e hutus já existiam anteriormente à colonização, e viviam em simbiose e de modo harmônico. Teria cabido ao processo colonial desenvolver o ódio entre os dois grupos, conforme Silva desenvolve no trecho destacado:

\begin{abstract}
O acirramento do ódio entre os diferentes grupos étnicos também foi o pano de fundo sobre o qual se desenhou o complicado xadrez de relacionamentos entre Tutsis e Hutus em Ruanda. A clivagem social, representada pelas hostilidades entre as duas etnias, foi sendo sulcada paulatinamente pelos colonizadores alemães e belgas desde os primeiros momentos da administração da região (...). ${ }^{25}$
\end{abstract}

Já para a versão que aponta que as características de tutsis e hutus, enquanto grupos étnicos, foram criadas e desenvolvidas pelo poder colonial, não interessa o que estes eram anteriormente a colonização, "o que quer que a identidade butu e tutsi tenba significado na situação précolonial não importa mais; os belgas haviam feito da 'etnicidade' o traço definidor da existência ruandesa". ${ }^{26}$ Esta divisão de uma etnicidade criada pelos belgas funcionaria de modo que ao dividir a sociedade ruandesa em dois grupos opostos, poderia dominá-la com uma maior facilidade - o tradicional dividir para dominar.

De qualquer modo para ambas as concepções, em 1959, quando ocorre a chamada Revolução Hutu, em que o poder monárquico é destituído de Ruanda, o modo de produção e reprodução da vida dos hutus e dos tutsis já estava consolidado da mesma maneira que se apresentaram no genocídio em 1994. Conforme aponta Alves (2005),

Nas narrativas tradicionais sobre o genocídio ruandês, "tutsis" e "hutus" já aparecem sua forma "acabada" no pós-revolução de 1959. A partir do estabelecimento do

\footnotetext{
24 KAPUSCINSKI, Ryszard. Ébano: Minha vida na Africa. São Paulo, Companhia das Letras, 2002.

25 SILVA, Alexandre S. A intervenção bumanitária em três quase-Estados africanos: Somália, Ruanda e Libéria. Dissertação (mestrado). Pontifícia Universidade Católica do Rio de Janeiro, Instituto de Relações Internacionais, 2003, p. 69.

${ }^{26}$ GOUREVITCH, Philip. Gostaríamos de informá-lo de que amanhã seremos mortos com nossas famílias. São Paulo, Companhia das letras, 2006, p. 56.
} 
Estado ruandês independente e de suas respectivas instituições cessa toda a discussão socioconstrutiva. A partir daí, Tutsi e hutus não mudam mais, deixando de ser construídos enquanto tais categorias - e que dirá de se autoconstituírem. O processo é congelado (...), e a discussão passa a ser a "luta pelo poder". A história é naturalizada, e a historicidade, extinta. ${ }^{27}$

O fim do se fazer histórico da população ruandesa também pode ser visto como um fator sintomático do etnocentrismo dos analistas, já que ocorre ai uma periodização bastante significativa. De acordo com esta, a partir do momento em que ocorre a saída do agente histórico externo, a população ruandesa deixa de se fazer historicamente, passando para uma simples "luta pelo poder".

\section{Considerações finais}

A partir das concepções acerca da história ruandesa, expostas no decorrer do artigo, podemos assegurar que este conjunto de visões que permeia a historiografia dominante acerca do evento estudado pode ser visto como essencialmente etnocêntricas. Esta característica é visível em cinco pontos distintos que normalmente permeiam as analises etnocêntricas:

- “A ideia que os contatos com o Ocidente são o fundamento da bistoricidade das outras culturas": ${ }^{28}$ pudemos observar no decorrer do artigo que muitas vezes os eventos entendidos como determinantes para o processo histórico ruandês são aqueles causados pelo contato com o mundo ocidental. Assim como ocorre numa série de análises etnocêntricas acerca do desenvolvimento histórico africano, o evento posto como o início deste processo, é a Conferência de Berlim de 1885, ou seja, a história africana só começaria, ou sairia de uma antiga inércia, a partir do momento em que ocorreu uma enorme intervenção ocidental. $\mathrm{Na}$ análise acerca de Ruanda não foi diferente. A própria Conferência de Berlim e seu consequente processo colonial alemão e belga são postos como fundamentais para o genocídio, principalmente como um gestor das relações entre tutsis e hutus, seja esta relação previamente existente, ou nova. A saída dos agentes históricos externos também traz uma nova estagnação no se fazer histórico dos ruandeses, já que com a Revolução hutu de 1959 e a expulsão do poder colonial, as relações sociais já estão prontas para engendrar o genocídio.

\footnotetext{
27 ALVES, Ana Cristina. Contos sobre Ruanda: Uma análise crítica sobre o genocídio ruandês de 1994. Dissertação (mestrado) - Pontifícia Universidade Católica do Rio de Janeiro, Instituto de Relações Internacionais, 2005, p. 73. ${ }^{28}$ LE GOFF, Jacques. História e Memória. Campinas, Editora da Unicamp, 1990, p 138.
} 
- "A legitimaşão unilateral das ações ocidentais" ${ }^{29 ": ~ u m ~ p o n t o ~ c r u c i a l ~ d e n t r o ~ d a ~ a n a ́ l i s e ~ d o ~}$ etnocentrismo é uma aceitação sem muitos questionamentos do agir histórico ocidental sobre outras sociedades. No caso da análise etnocêntrica do genocídio ruandês, ocorre um entendimento quase que natural do processo de avanço do cristianismo, assim como, um constante reforço de que a não intervenção da comunidade internacional foi uma das responsáveis pelo genocídio. Ao se reforçar constantemente a necessidade de uma intervenção externa, principalmente da ONU, deixa-se de lado a ação dos agentes sociais locais, o que está intimamente interligado com outro ponto etnocêntrico fundante das análises acerca do genocídio ruandês.

- A desvalorização dos agentes históricos locais: O processo histórico ruandês foi entendido muitas vezes sem valorizar os seus próprios agentes sociais. Ou seja, os acontecimentos históricos do país se davam devido à ação de agentes estrangeiros, ou até na não ação destes agentes - no caso de se entender o genocídio ruandês como sendo proveniente da não intervenção ocidental. Esta desvalorização, ou marginalização, dos agentes históricos ruandeses resultou numa série de estereótipos feitos pelo mundo ocidental, que trazem um entendimento ainda mais pobre de tal processo, colocando os ruandeses como pessoas bárbaras e selvagens, e definindo as tensões entre tutsis e hutus como algo proveniente de conflitos tribais. Os estereótipos postos na análise etnocêntrica são oriundos de um profundo enraizamento do evolucionismo social e do processo civilizatório.

- Evolucionismo social e o processo civilizatório: a grande base do etnocentrismo está enraizada na concepção de um desenvolvimento unitário das sociedades humanas, todas estas percorreriam dentro de seu processo histórico numa mesma escala evolucionária social, passando por etapas pré-determinadas até atingir o seu ápice, o qual seria a civilização ocidental. Desta forma, as visões etnocêntricas ocidentais acabam por entender outras sociedades humanas a partir de seu próprio desenvolvimento histórico, o que leva a uma série de entendimentos rasos, classificando outras formas societárias como primitivas ou bárbaras, em contraposição à suposta civilidade e desenvolvimento ocidental. Assim, o genocídio ruandês é posto como uma mera atitude de uma população bárbara que vive num estado primitivo, ainda distante da civilização ocidental.

\footnotetext{
${ }^{29}$ LE GOFF, Jacques. História e Memória. Campinas, Editora da Unicamp, 1990, p 138.
} 
Todas as concepções acerca do genocídio ruandês, aqui apresentadas, não possibilitam um pleno entendimento deste complexo episódio da história recente, apesar de em alguns momentos ocorrerem críticas pertinentes ao fato, mas de qualquer modo não se atinge uma explicação profunda. Para se atingir este entendimento pleno dos acontecimentos de abril a julho de 1994 em Ruanda, é preciso entender a lógica cultural interna da população ruandesa, buscando suas representações, simbologias e práticas sociais indo além de um olhar ocidental. Mas sem esquecer o duro embate e tensão que o contato com o mundo ocidental causou. De qualquer modo, todo este choque só pode ser entendido a partir do sujeito histórico ruandês e não com bases ocidentais que levam a sua negação.

\section{Bibliografia}

1. ALVES, Ana Cristina. Contos sobre Ruanda: Uma análise crítica sobre o genocídio ruandês de 1994. Dissertação (mestrado) - Pontifícia Universidade Católica do Rio de Janeiro, Instituto de Relações Internacionais, 2005.

2. APPIAH, Kwame Anthony. Na casa de meu pai: a África na filosofia da cultura. Rio de Janeiro, Contraponto, 1997.

3. BARBOSA, Muryatan. Eurocentrismo, História e História da Africa, in: Sankofa Revista de História da África e de Estudos da Diáspora Africana No 1 jun./2008

4. BENJAMIN, Walter. "Sobre o conceito da História". In: Magia, Técnica, Arte e Política. São Paulo: Brasiliense, 1994.

5. BERKELEY, Bill. The graves are not yet full: Race, tribe and power in the heart of África. New York, Basic book, 2001

6. BLOCH, Marc. Apologia da bistória, ou, O ofício de historiador. Rio de Janeiro, Jorge Zahar Ed., 2001.

7. BRUNSCHWIG, Henri. A partilha da Africa negra. São Paulo, Editora Perspectiva, 1974.

8. CLAY, Daniel. KAMPAYANA, Theobald. KAYITSINGA, Jean. Inequality and the emergence of Non-farm employment in Rwanda, Michigan, 1990.

9. CLAY, Daniel. LEWIS, Laurence. Land use, soil loss and sustainable agriculyure in Rwanda. New York, Plenuem Press, 1996.

10. COSTA, Emilia Viotti da. Coroas de Glória, Lágrimas de Sangue. São Paulo: Companhia das Letras, 1998.

11. EVERAERTS, E. Monographie Agricole du Ruanda-Urundi, Bruxelas, Direction de l'Agriculture et de l'évage, 1947. 
12. FERRO, Marc. História das colonizações: das conquistas as independências, séc XVIII a XX. São Paulo, Companhia das Letras, 1996.

13. GOUREVITCH, Philip. Gostariamos de informá-lo de que amanbã seremos mortos com nossas famílias. São Paulo, Companhia das letras, 2006.

14. HATZFELD, Jean. Uma temporada de facões: relatos do genocídio em Ruanda. São Paulo, Companhia das Letras, 2005.

15. . Na nudeż da Vida: relatos dos pântanos de Ruanda. Lisboa, Caminho, 2002.

16. HOCHSCHILD, Adam. O fantasma do Rei Leopoldo: uma história de cobiça terror e heroísmo na África colonial. São Paulo, Companhia das Letras, 1999.

17. KAPUSCINSKI, Ryszard. Ébano: Minha vida na África. São Paulo, Companhia das letras, 2002.

18. KEATING, Vincent. Etbnicity and the Rwandan Genocide, 2005

19. LE GOFF, Jacques. História e Memória. Campinas, Editora da Unicamp, 1990

20. LEITE, Leila. A África na sala de aula: vista a história contemporânea. São Paulo, Selo Negro Edições, 2005.

21. LEURQUIN, Philip. Le Nivean de Vie des populations rurales de Ruanda-Urundi. Lovain,1960.

22. MANDANI, Mahmood. When victims become killers: colonialism, nativism and the genocide in Rwanda, Princeton, Princeton University Press, 2002.

23. NEWBURY, Catharine. Ethnicity and the politics of history in Rwanda. África Today, n 44, v. 2, 1997.

24. OLIVEIRA, Roberto. Etnia e Identidade. São Paulo, Pioneira,1976

25. RICART, Maria del Carmen. Ruanda, un camino de esperanza: Primeros tiempos de la evangelización de Ruanda, Valencia, Edicep, 1998.

26. RUCYAHANA, John. The bishop of Rwanda. Nashville, Thomas Nelson, 2006

27. SAID, Edward. Orientalismo: oriente como invenção do ocidente, São Paulo, Companhia das Letras, 1990.

28. SILVA, Alexandre S. A intervenção bumanitária em três quase-Estados africanos: Somália, Ruanda e Libéria. Dissertação (mestrado) - Pontifícia Universidade Católica do Rio de Janeiro, Instituto de Relações Internacionais, 2003.

29. SILVA, Alberto da Costa e. A enxada e a lança: a África antes dos portugueses, São Paulo, Nova fronteira, 2005.

30. SONTAG, Susan. Diante da dor dos outros. São Paulo, Companhia das Letras, 2003.

31. STRAUS, Scott. The order of the genocide: race, power, and war in Rwanda, Ithaca, Cornell University Press, 2006 
32. TAKEUSHI, S. MARARA, J. Conflict and Land tenure in Rwanda. Tokyo, Jica Research, 2009, p. 8.

33. TARDIF-DOUGLIN, David, NGIRUMWAMI, Jean-Léonard, SHAFFER, Jim, MUREKEZI, Anastase, KAMPAYANA, Théobald. Finding the balance between agricultural and trade policy: Rwanda coffee policy in flux. Michigan, MSU International development, Working Paper No. 59, 1996.

34. THOMPSON, Edward. Costumes em comum. São Paulo: Companhia das Letras, 1998.

35. . A miséria da teoria ou um planetário de erros. Rio de Janeiro: Zahar Editores, 1981.

36. VERWIMP, Philip. Develoment Ideology, the Peasantry and genocide: Rwanda represented in Habyarimana's speeches. Yale, GSP Working Paper No. 13, 1998.

37. WESSELING, H. L. Dividir para dominar: A partilha da África (1880-1914). Rio de Janeiro, Ed da UFRJ, 1998.

38. WILliANS, Raymond. Cultura. São Paulo: Paz e Terra, 1992.

\section{Artigo recebido em: 30/05/2011}

Aceito para publicação em: 22/06/2011 